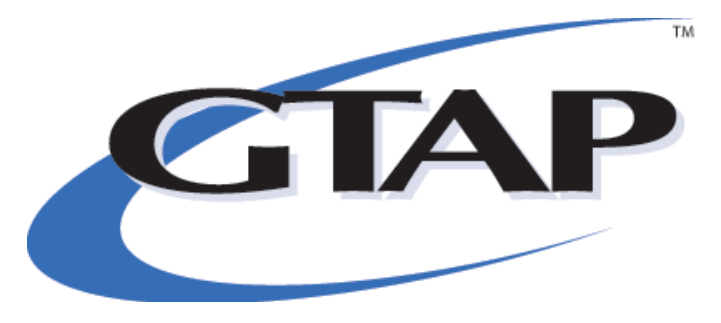

\title{
The Opportunity Cost of Land Use and the Global Potential for Greenhouse Gas Mitigation in Agriculture and Forestry
}

\author{
by
}

Alla Golub*, Thomas Hertel ${ }^{*}$, Huey-Lin Lee ${ }^{\dagger}$, Steven Rose ${ }^{\ddagger}$, and Brent Sohngen ${ }^{\S}$

REVISED May 13, 2008

GTAP Working Paper No. 36

2008

Center for Global Trade Analysis (GTAP), Purdue University, golub@purdue.edu

Corresponding author is Thomas Hertel, Center for Global Trade Analysis (GTAP), Purdue

University, hertel@purdue.edu

NIES. Email: hueylin_lee@yahoo.com

United States Environmental Protection Agency. Email: rose.steven@epamail.epa.gov

The Ohio State University. Email: sohngen.1@osu.edu 


\title{
THE OPPORTUNITY COST OF LAND USE AND THE GLOBAL POTENTIAL FOR GREENHOUSE GAS MITIGATION IN AGRICULTURE AND FORESTRY
}

\author{
Alla Golub, Thomas Hertel, Huey-Lin Lee, Steven Rose, and Brent Sohngen
}

\begin{abstract}
This paper analyzes the role of global land-use in determining potential greenhouse gas mitigation by land-based activities in agriculture and forestry. Land-based activities are responsible for over a third of global greenhouse gas emissions, yet the economics of land-use decisions have not been explicitly modeled in global mitigation studies. In this paper, we develop a new, general equilibrium framework which effectively captures the opportunity costs of land-use decisions in agriculture and forestry, thereby allowing us to analyze competition for heterogeneous land types across and within sectors and input substitution between land and other factors of production. In our analysis of carbon taxation, we find significant changes in the global pattern of comparative advantage as a result of differential mitigation costs across sectors, regions, and land types. We find that forest carbon sequestration is the dominant strategy for GHG emissions mitigation globally in the land using sectors. However, when compared to the rest of the world, land-use emissions abatement in the US and China comes disproportionately from agriculture, and, within agriculture, disproportionately from reductions in fertilizerrelated emissions. In the world as a whole, agriculture-related mitigation comes predominantly from reduced methane emissions in the ruminant livestock sector, followed by fertilizer and methane emissions from paddy rice. The results also show how analyses that only consider regional mitigation may under- or over-estimate mitigation potential. For example, U.S.-specific analyses likely over-estimate the potential for abatement in agriculture. Finally, we note that this general equilibrium framework provides the research community with a practical methodology for explicit modeling of global land competition and land-based mitigation in comprehensive assessments of greenhouse gas mitigation options.
\end{abstract}

JEL: C68, Q15, Q54.

Keywords: climate change, land use change, non-CO2 greenhouse gas, marginal abatement cost, computable general equilibrium, carbon sequestration. 


\section{Table of Contents}

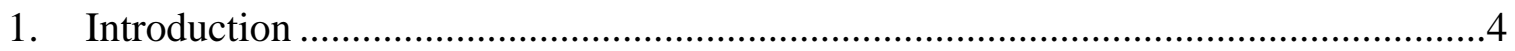

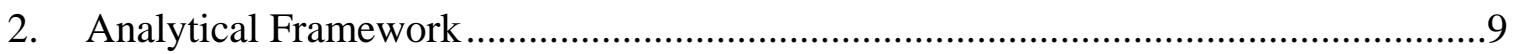

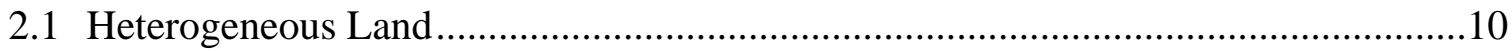

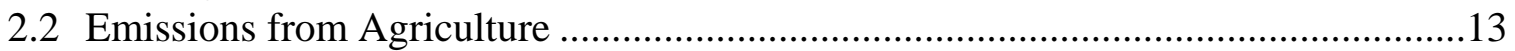

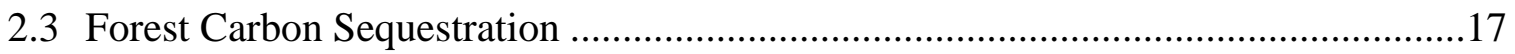

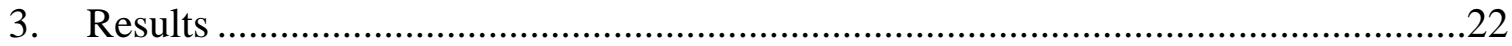

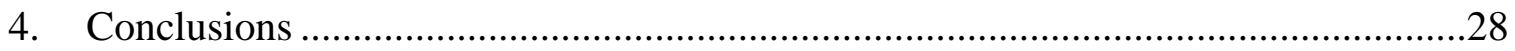

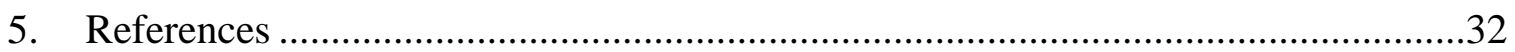

Table 1. Land rents at market price by AEZ and sector for the USA and China (million 2001 US\$)......................................................................36

Table 2. Non- $\mathrm{CO}_{2}$ GHG emissions by agricultural sector and emissions source (MMTCE).............................................................................37

Table 3. Key initial emission intensities ( $\mathrm{MtC} / \$$ of input, where $\mathrm{MtC}=1000 \mathrm{Kg} \mathrm{C}$ ).

Table 4. Elasticities of substitution: Shaded boxes denote elasticities calibrated for emissions mitigation and sequestration...........................38

Table 5. Carbon sequestration supply schedule: by category, annual equivalent abatement over 20 years (MMTCE).

Table 6. General equilibrium impact of emissions taxes on net emissions in each region following a global tax of \$100/TCE in agricultural sectors and forestry

Table 7. Percentage changes in agricultural output levels and input intensities following a \$100/TCE global carbon tax in agricultural sectors and forestry .....

Table 8. Percentage changes in rental share weighted land use, by AEZ and sector in USA and China due to a \$100/TCE global carbon tax in land using sectors

Table 9. Changes in regional trade balances due to a \$100/TCE global carbon tax in agricultural sectors and forestry.....

Figure 1a. Global general equilibrium GHG abatement supply schedules. .43

Figure 1b. Global agriculture subsector GHG abatement supply schedules 


\title{
THE OPPORTUNITY COST OF LAND USE AND THE GLOBAL POTENTIAL FOR GREENHOUSE GAS MITIGATION IN AGRICULTURE AND FORESTRY
}

\author{
Alla Golub, Thomas Hertel, Huey-Lin Lee, Steven Rose, and Brent Sohngen
}

\section{Introduction}

Changes in land use and land cover represent an important driver of net greenhouse gas (GHG) emissions. It has been estimated that roughly a third of the total emissions of carbon into the atmosphere since 1850 has resulted from land use change (and the remainder from fossil-fuel emissions) (Houghton, 2003). For example, in the 1990s, 6.4 billion tonnes of carbon equivalent (BTCE) per year was emitted to the atmosphere from industrial activities and 2.2 BTCE per year was emitted from tropical deforestation. ${ }^{1}$ In addition, agricultural land related activities are estimated to be responsible for approximately 50\% of global methane emissions $\left(\mathrm{CH}_{4}\right)$ and $75 \%$ of global nitrous oxide $\left(\mathrm{N}_{2} \mathrm{O}\right)$ emissions, for a net contribution from non-carbon dioxide (non- $\mathrm{CO}_{2}$ ) GHGs of approximately 14\% of all anthropogenic greenhouse gas emissions (USEPA, 2006a). Because of this potentially important role in the climate change debate, the policymaking community is assessing how agriculture and forestry may enter into future climate policies. These come into play, either as domestic actions (e.g., emission offsets within a cap-and-trade system), or via mechanisms for achieving international commitments for emissions reductions (e.g., the Clean Development Mechanism). In this paper, we develop a new framework for assessing the mitigation potential of land-based emissions that explicitly models the economics of land-use decisions. This framework

\footnotetext{
${ }^{1}$ Throughout this paper, carbon is measured in metric tonnes, where 1 metric tonne $=1000 \mathrm{Kg}$. Metric tonnes of carbon equivalent are written as "TCE", million metric tonnes are written as "MMTCE", and billion metric tonnes are written as "BTCE."
} 
could be readily combined with existing GHG mitigation studies of industrial and fossil fuel-based GHG emissions.

A number of estimates have been made of the cost of abating greenhouse gas emissions for specific land use change and land management technologies (Richards and Stokes, 2004; USEPA, 2006b, Chapter 5). Recent studies also suggest that land-based mitigation could be cost-effective and assume a sizable share of overall mitigation responsibility in optimal abatement (Sohngen and Mendelsohn, 2003) and stabilization policies (Rose et al., 2008). However, to date, global economic modeling of land has not been able to fully account for the opportunity costs of land-use and land-based mitigation strategies, nor the heterogeneous and dynamic environmental and economic conditions of land (e.g., Li et al., 2006; Sohngen et al., 2008).

Despite the clear links between the agricultural and forestry sectors through land and other factor markets and international trade, existing studies do not explicitly model the reallocation of inputs (factor and intermediate) within and across these and other sectors and regions in response to climate policies. National and international agricultural and forest climate policies have the potential to redefine the opportunity costs of international land-use in ways that either complement or counteract the attainment of climate change mitigation goals. This paper develops an analytical framework to capture and evaluate these potentially important relationships.

Global economic modeling of land-use is not new. There are global agricultural models (e.g., Darwin et al., 1995, 1996; Ianchovichina et al., 2001; Rosegrant et al., 2001), and global forestry models (e.g., Sohngen and Sedjo, 2006), and some that endogenously model land competition between the two sectors (Sands and Leimbach, 
2003). There are other models that employ priority rules that allocate land to food crops first before serving other commodity markets such as timber demand (e.g., Riahi et al., 2006, van Vuuren et al., 2006).

In terms of economic-based land modeling focused on GHG mitigation, studies of the global supply of forest carbon sequestration have evolved and become relatively mature, with globally consistent dynamic frameworks modeling endogenous movement of land in and out of forestry, explicit consideration of multiple forest management alternatives and forest types, and modeling of international trade effects (e.g., Sohngen and Mendelsohn, 2007; Sohngen and Sedjo, 2006; Sathaye et al., 2006; Rokityanskiy et al., 2006). However, the same cannot be said for global studies of agricultural greenhouse gas mitigation potential. A single consistent economic framework does not exist to evaluate global mitigation potential (Chapter 8, IPCC, 2007). Instead, global estimates are derived from a variety of existing disparate global biophysical and economic modeling results (e.g., Smith et al., 2007) or modeled exogenously or within large sector or GHG aggregates (Fawcett and Sands, 2006; van Vuuren et al., 2006; Reilly et al., 2006). Meanwhile, regional studies have illustrated the importance of land-use competition in agricultural and forestry greenhouse gas mitigation (Murray et al., 2005), but have yet to endogenize land input and budget allocation decisions in economy-wide modeling (e.g., McCarl and Sands, 2007).

Meanwhile, recent results from a variety of modeling teams found non- $\mathrm{CO}_{2}$ GHG mitigation (across all sectors) to be a cost-effective means of achieving long-term climate stabilization goals—providing substantial cost savings by reducing the mitigation necessary from fossil fuel and industrial $\mathrm{CO}_{2}$ emissions sources (de la Chesnaye and 
Weyant, 2006). However, these studies do not account for the implications of carbon policies on the net returns of different global land uses and land management decisions, the economy-wide effects of changes in the relative prices of production factors, or for the competition between uses for the same land. Failure to account for land mobility, changing prices, and input substitution, within agriculture and between agriculture and forestry is likely to result in misleading estimates of the marginal cost of mitigation for $\mathrm{CO}_{2}$ and non- $\mathrm{CO}_{2}$ greenhouse gases (e.g., Lee, 2004). As shown by Klepper and Peterson (2006), regional abatement potential will be influenced by changes in world prices induced by production changes following abatement of emissions. Klepper and Peterson focus on the impact of changes in the price of oil. This paper considers changes in relative prices in regional and global input and output markets associated with GHG abatement in agriculture and forestry.

Computable general equilibrium (CGE) economic models are well suited to evaluate these kinds of tradeoffs, and have been extensively used in the climate change policy debate. Existing CGE frameworks, however, are not currently structured to model land use alternatives and the associated emissions sources and mitigation opportunities. This work has been hindered by a lack of data, such as consistent and disaggregated global land resources and non- $\mathrm{CO}_{2}$ GHG emissions databases linked to underlying economic activity and GHG emissions and sequestration drivers. This paper is the first to adopt new global land-use and emissions datasets (Ramankutty et al., 2007; Monfreda et al., 2008; Sohngen et al., 2008; Rose et al., 2008b), as well as new engineering mitigation costs estimates (USEPA, 2006b) in global land use modeling.

This analysis develops CGE estimates of global land-use GHG abatement 
potential in the near-term, a period of 20 years. Using the newly available land and emissions datasets, we construct a novel globally consistent modeling framework to understand how different land-use opportunities for GHG abatement interact with one another and the rest of the economy on both regional and global scales, taking into account global market clearing conditions for commodities.

The CGE framework has intra- and inter-regional land and GHG emissions and sequestration heterogeneity. In addition, we develop a much more disaggregated emissions and forest sequestration modeling structure than that which is currently utilized in the general equilibrium climate change literature. In our analysis, we capture more refined agricultural production responses in GHG mitigation by distinguishing three types of mitigation responses: those associated with intermediate input use (e.g., nitrous oxide emissions from fertilizer use in crops), those associated with primary factors (e.g., methane emissions paddy rice), and those associated with sector outputs (e.g., methane emissions from agricultural residue burning). Because forestry and agricultural markets compete for the same land, we have also developed a method for modeling forest intensification (e.g., timber management) decisions separately from forest extensification (e.g., land-use change) decisions. The goal is to better capture land related GHG emissions and sequestration sources and mitigation decisions within an economy-wide framework. Specifically, we enhance the standard GTAP global economic database with disaggregated land endowments and land use (Lee et al., 2008), detailed non- $\mathrm{CO}_{2}$ greenhouse gas emissions data linked directly to economic sectors and emissions drivers (Rose and Lee, 2008), and explicit modeling of forestry intensification and extensification. 
We then analyze land allocation decisions and general equilibrium market feedbacks under emissions taxation policies. Special attention is paid to the land-using activities, including forestry, paddy rice, other cereals, other crops and livestock grazing. We derive estimates of the general equilibrium GHG mitigation potential for agriculture and forestry activities, such as livestock production, rice cultivation, nitrogen fertilizer applications, and carbon sequestration in forestry.

\section{Analytical Framework}

We develop a modified version of the standard GTAP model (Hertel, 1997) GTAP-AEZ-GHG — that incorporates different types of land and related GHG emissions and sequestration into the GTAP modeling framework. In so doing, we follow the pathbreaking work of Darwin et al. $(1995,1996)$ which brings climatic and agronomic information to bear - defining different types of productive land via Agro-Ecological Zones (AEZs). Given our interest in elucidating land competition and the opportunity costs of land-based greenhouse gas mitigation technologies, we focus on non- $\mathrm{CO}_{2} \mathrm{GHG}$ emissions from agriculture and forest carbon sequestration. We intentionally ignore fossil fuel combustion $\mathrm{CO}_{2}$ emissions, with the exception of our concluding section, as the costs of abatement through these channels are well covered in the existing literature (e.g., Hourcade et al., 2001). ${ }^{2}$ Furthermore, we modified the standard GTAP model to tie emissions and sequestration more directly to the underlying economic drivers and thereby allow for cost-minimizing responses to emissions taxes.

\footnotetext{
${ }^{2}$ Other non-fossil fuel $\mathrm{CO}_{2}$ emissions and mitigation options are not considered in this analysis. Of particular relevance here are biomass burning as well as crop and pasture land soil carbon stocks. These emissions and sequestration categories will be integrated into the GTAP GHG emissions datasets in the future, thereby enabling consideration in modeling. However, non- $\mathrm{CO}_{2}$ emissions from agricultural biomass burning are currently included.
} 
We decided to constrain our regional disaggregation to three regions (U.S., China, and Rest of World) in order to focus on the implications and insights from our new modeling approaches. Isolating the U.S. and China allows us to evaluate the responses of regions with very different levels of economic development, and rather different agricultural and forestry sectors. The rest of the world is then simply aggregated. We model 24 sectors, including all the major land-based emitting sectors and primary and secondary food and timber markets, as well as other sectors necessary to link these to the economy at large. The main point of the paper is to develop new methodology. Adding more regions or sectors would simply proliferate numbers and obscure insights from the enhanced modeling structure.

\subsection{Heterogeneous Land}

Given our interest in modeling the competition for land, it is important to recognize that land is a heterogeneous endowment. Just as general equilibrium analyses of labor markets should disaggregate labor by skill level, so too should analyses of land markets disaggregate land by productivity. A natural way of doing so is to identify AgroEcological Zones (AEZs) following Darwin et al. (1995). In this study, we distinguish 18 AEZs, which differ along two dimensions: growing period (6 categories of 60 day growing period intervals), and climatic zones (3 categories: tropical, temperate and boreal). Following the work of the FAO and IIASA (2000), the length of growing period depends on temperature, precipitation, soil characteristics and topography. The suitability of each AEZ for production of alternative crops and livestock is based on currently observed practices, so that the competition for land within a given AEZ across uses is constrained to include activities that have been observed to take place in that AEZ. 
As with virtually all CGE models, inputs in our model are measured in economic value terms. Table 1 reports the land rents attributable to the five land-using sectors in our model, across the 18 AEZs in both China and USA. Several points are immediately apparent. First of all, for any given activity, the distribution of land rents across AEZs is not uniform - nor is it the same for different land using sectors. For example, the largest land expenditures for paddy rice are in the longest growing period temperate zones (AEZs 11 and 12), whereas for ruminant grazing, they are in the shorter growing period temperate and boreal zones (AEZs 7, 8, and 13-15). Other grains (maize and wheat) cropping activity is more pronounced in AEZ 9 in China and 10 and 11 in USA. The main economic competition between forestry and cropping is in the longest growing period temperate AEZ (AEZ 12: the Southeastern USA).

Our GTAP-AEZ-GHG framework retains a single, national production function for each commodity (as in the standard GTAP model), and introduces different AEZs as inputs to this national production function (see also Darwin et al., 1995; Eickhout et al., 2008). With a sufficiently high elasticity of substitution between AEZ's, we are assured that the return to land across AEZs, but within a given use (or sector), will move closely together, as would be the case if we had modeled production of a given homogeneous commodity on each AEZ separately (see the Appendix for a proof of this point).

We constrain land supply across alternative uses (or sectors), within a given AEZ, via a Constant Elasticity of Transformation (CET) frontier. Thus, for example, the within-AEZ returns to land in forestry and maize production are allowed to differ. This also constrains the partial equilibrium supply response of land to any given sector to remain in line with the econometric literature. The absolute value of the CET parameter 
represents the upper bound (the case of an infinitesimal rental share for that use) on the elasticity of supply to a given use of land in response to a change in its rental rate. The lower bound on this supply elasticity is zero (the case of a unitary rental share - whereby all land is already devoted to that activity).

We follow the nested CET, land supply approach of Darwin et al. $(1995,1996)$, as well as Ahammad (2006). In this framework, land owners first decide on the optimal land mix among crops. The land owner then decides on the allocation of land between crops and livestock based on the composite return to land in crop production, relative to the return in ruminant livestock production. This also determines the average return to land allocated to agriculture (crops and livestock sectors) in general. This return is compared to that in forestry in order to determine the broad allocation of land between these two land-using sectors.

Calibration of the CET land supply functions in the model is based on the available econometric evidence which suggests that the elasticity of transformation between agricultural land and forest land is less than that between grazing and crop land, and both are less than the elasticity of transformation between crop types. The most important elasticity for purposes of this paper is the elasticity of land supply to forestry, as forest sequestration subsidies send a strong signal to expand forest land. This is given a maximum value of 0.25 , based on the econometric work of Choi (2004) for the United States. So -0.25 becomes the elasticity of transformation between agriculture and forest lands. The other transformation elasticities are set at 0.5 (crops vs. livestock) and 1.0 (elasticity of transformation amongst crops), respectively. 


\subsection{Emissions from Agriculture}

As documented by Rose and Lee (2008), non- $\mathrm{CO}_{2}$ emissions from agriculture (crops and livestock) represent well over $50 \%$ of China's total non- $\mathrm{CO}_{2}$ emissions (in carbon equivalent units), just under half of U.S. non- $\mathrm{CO}_{2}$ emissions, and just over $60 \%$ of global non- $\mathrm{CO}_{2}$ emissions. A detailed breakdown, for the agricultural sectors that are the focus of this paper, is provided in Table 2. In the case of USA, methane emissions from enteric fermentation, as well as nitrous oxide emissions from crop production are large sources of emissions. These sources are also important in China, as are methane emissions from paddy rice cultivation. China also has significant methane emissions from its production of pigs and other non-ruminants. In the rest of the world (ROW), the top categories of emissions are methane from ruminant livestock production, paddy rice cultivation and biomass burning, and nitrous oxide emissions associated with nitrogen applications to crops and pasture lands. From the region totals (italicized entries) in Table 2, we see that the US and China account for $8 \%$ and $18 \%$ of global agricultural non- $\mathrm{CO}_{2}$ emissions, respectively.

The emissions data in Table 2 were developed from a detailed non- $\mathrm{CO}_{2}$ greenhouse gas emissions database specifically designed for use in global economic models (Rose et al., 2008b). It provides highly disaggregated emissions information that we mapped directly to countries and economic sectors utilizing of available input quantity data (Rose and Lee, 2008). The result allows for a more robust and refined representation of non- $\mathrm{CO}_{2}$ emissions sources in economic models and improved modeling of actual emitting activities and abatement strategies. ${ }^{3}$ For instance, as shown in

\footnotetext{
${ }^{3}$ Other global emissions datasets have provided valuable regional and global estimates (e.g., USEPA, 2006a; Olivier, 2002); however, estimated emissions have been developed and presented according to
} 
Table 2, non-CO2 ruminant emissions come from manure management, enteric

fermentation, fossil fuel combustion, and grazing activity, each of which can be managed separately or in combination.

To model and evaluate the general equilibrium input allocation responses to mitigation policies, we tied non- $\mathrm{CO}_{2}$ emissions to explicit input or output levels. More specifically, the methane emissions associated with paddy rice production are tied to acreage cultivated, as the emissions tend to be proportional to the amount of paddy rice land . Nitrous oxide emissions from maize production are tied to fertilizer use. Emissions associated with enteric fermentation, manure management in non-ruminants are tied to livestock capital, whereas in ruminants they are tied to output (discussed below). Emissions from biomass burning, and stationary and mobile combustion are tied to sector output.

Any given emissions entry in Table 2 may be large because the economic activity in the sector is large (e.g., a large dairy sector), or it may be large due to a high level of emissions per dollar of input. The latter is the "emissions intensity" of a given activity, and this intensity is critical in determining the impact of a carbon-equivalent emissions tax on a given sector. The ad valorem impact of the carbon tax depends on the product of the per unit tax and the emissions intensity of the taxed activity. Table 3 reports some key emissions intensities from the model for each region. USA has the highest emissions

IPCC source categories that aggregate across countries, and more importantly, economic sectors and activities. The USEPA database provides 2001 emissions for 29 non- $\mathrm{CO}_{2}$ and Other $\mathrm{CO}_{2}$ GHG emissions categories with 153 unique emissions sources (subcategories) for 226 countries. Most of the USEPA categories and subcategories were mapped into GTAP (24 categories and 119 subcategories). The excluded categories/subcategories include non- $\mathrm{CO}_{2}$ emissions associated with biomass burning not uniquely attributable to anthropogenic activity, tropical forest fire deforestation, biomass combustion, underground storage and geothermal energy, and Other $\mathrm{CO}_{2}$ emissions not attributable to fossil fuel combustion. The omitted emissions subcategories will be added to the database in the future as methodologies are developed 
intensity in fertilizer, but China has the highest emissions intensity for ruminants and paddy rice. These are the regions/activities where we would expect to see relatively stronger reductions in emissions following a uniform global carbon tax. ${ }^{4}$

As with most CGE analyses, our model represents technology via a set of production functions in which the key parameters are elasticities of substitution amongst groups of inputs. These may be viewed as smooth approximations to dozens - even hundreds - of underlying technologies, each with their own factor intensities. As the price of one input, say fertilizer, rises, firms are expected to adopt less fertilizer-intensive practices. In our framework, the scope for conservation of fertilizer is captured by the elasticity of substitution between fertilizer and other inputs. If this is large, then a small tax on fertilizer use will induce a large reduction in fertilizer use. If the elasticity is small, then it will take a large tax to induce a significant reduction in fertilizer usage at a given level of crop output. These elasticities of substitution are central to the determination of marginal abatement costs for emissions from various activities in our model.

The U.S. Environmental Protection Agency (USEPA) has estimated the engineering mitigation costs and emissions implications of alternative management strategies for key agricultural non- $\mathrm{CO}_{2}$ emissions sources—paddy rice, other croplands (wheat, maize, soybean), and livestock enteric and manure emissions (Chapter 5, USEPA, 2006). For calibrating the general equilibrium model, we constructed mitigation cost curves from the EPA data base that correspond to the GTAP-AEZ-GHG region and sector structure. Since we have tied many of the emissions to input drivers, we are able to

and activity data becomes available. The new dataset complements the GTAP fossil fuel combustion $\mathrm{CO}_{2}$ emissions database, and the GTAP forest carbon stock dataset (Sohngen et al., 2008).

${ }^{4}$ Note that emissions intensity is sometimes measured in terms of emissions per unit output. However, a high input emissions intensity does not necessarily translate into a high output emissions intensity. 
employ a more refined approach than that used by Hyman et al. (2003) for industrial emissions, which simply ties all emissions and mitigation to output levels.

Specifically, we introduce an additional layer of substitution elasticities into the production structure that allows for substitution between input-related emissions and specific inputs. Thus, for example, we allow paddy rice producers to respond to a methane emissions tax not only by using less land, but also by changing the emissions intensity of land (e.g., by changing irrigation and amendment practices). This additional flexibility allows us to consider alternative calibrations to the EPA abatement cost curves (USEPA, 2006b).

Before calibrating the GHG abatement responses, we calibrated the base input elasticities of substitution in production, both amongst intermediate inputs and valueadded and between elements of value-added. These parameters were calibrated to econometric estimates reported in a literature survey by the OECD (2001), following the approach suggested by Keeney and Hertel (2005). We begin the abatement response calibration by fixing output levels in the sectors, as well as input prices to match the partial equilibrium assumptions of the engineering cost estimates. We then proceed to vary the carbon equivalent price to map out a partial equilibrium abatement response for the relevant sector in each region. This response is compared to that of the EPA prediction at \$50/MtC. In the case of $\mathrm{N}_{2} \mathrm{O}$ emissions from fertilizer use in the crops sectors, the two abatement cost estimates are in remarkably good agreement, so no further adjustment is required. However, in the case of methane emissions from paddy rice production, the level of abatement predicted by our model is too low -- the econometrically estimated production function parameters suggest less scope for 
abatement than the US-EPA estimates. In this case, we add the possibility of changes in the input emissions intensity (recall Table 3). Specifically, we introduce scope for substitution between land and methane emissions in paddy rice production. Calibrated elasticities of substitution for China and ROW are given in the shaded entries of the first column of Table 4. The U.S. is a minor rice producing region, and regional abatement cost schedules are not available, so this elasticity is left at zero.

A similar situation arises with methane emissions from non-ruminant production, where we add the possibility of changes in the intensity of emissions per \$ of livestock capital. (See the shaded entries in that column of Table 4.) However, in the case of methane emissions from ruminant livestock production, the OECD (2001) calibrated production function gives a much larger abatement response than suggested by USEPA. In this case, we simply tie emissions to output and calibrate the substitution elasticity between emissions and output in order to replicate the EPA abatement estimate.

\subsection{Forest Carbon Sequestration}

Forest carbon stocks can be increased by increasing the biomass on existing forest acreage (the intensive margin) or by expanding forest land (the extensive margin). The former increases carbon storage per hectare with modifications of rotation ages of harvesting trees and management. The later afforests non-forested lands and prevents conversion of forest lands. First, we developed regional forest carbon supply curves using the partial equilibrium, dynamic optimization model of global timber markets and carbon stocks described in Sohngen and Mendelsohn (2007). ${ }^{5}$ We refer to this model as the

\footnotetext{
5 The model maximizes the net present value of consumers' surplus in timber markets less costs of managing, harvesting, and holding forests. In so doing, it determines the optimal age of harvesting trees (and thus the quantity harvested) in accessible regions, the area of inaccessible timber harvested, the area of
} 
"global timber model." Then, we calibrated the CGE model's regional responses to the curves.

We mapped out the carbon supply curves by introducing a range of carbon prices to the global timber model. The endogenous variables (e.g., harvest age, harvest area, land use change, and timberland management) adjust to maximize net surplus in the timber market and the benefits from carbon sequestration. Cumulative carbon sequestration in each period is calculated as the difference between total carbon stored in the carbon price scenario and that in the baseline case where there is no carbon tax.

The global timber model can simulate long-run carbon sequestration potential by decade for 100 years. Because of our "near-term" focus, we consider the potential for sequestration in a single "representative" year within the first 20 years. Specifically, we calculate the present value of cumulative sequestration over the first 20 years, and then calculate the annual equivalent amount. We use a 5\% discount rate, the rate assumed by the global timber model. The results are reported in Table 5 for the three GTAP-AEZGHG regions.

Carbon sequestration in each region is decomposed into the amount derived from land use change, aging of timber, and modified management of existing forests. The land use change component is what we refer to as the "extensive" margin, and it is reported in the first column of Table 5. These entries are determined by assessing the annual change in forestland area, tracking new hectares in forests compared to the baseline due to afforestation and avoided deforestation, and tracking the carbon on those hectares. For regions that undergo afforestation in response to carbon policies (typically temperate 
regions), carbon on new hectares are tracked by age class so that the accumulation of carbon on new hectares occurs only as fast as the forests grow. Therefore, there is little gained from reductions in deforestation in the temperate forests of the USA and China and smaller benefits from land use change are expected in initial periods in these two countries, while larger benefits are expected in tropical regions in initial periods. We see this in Table 5, where the carbon storage at \$5/TCE due to land use change is very small in USA and China. For regions where reductions in deforestation are a primary action in climate policy (typically tropical regions) the reductions in deforestation have an instantaneous effect on carbon, because they maintain a carbon stock that would otherwise be lost. Thus, the sequestration potential is quite large (143 MMTCE on an annualized basis) in the ROW region. Therefore the extensive margin portion of the forest sequestration supply curve for ROW is initially quite flat, indicating considerable sequestration potential with modest cost increases.

The combined effect of management and aging represent the "intensive” margin for sequestration, as they reflect the stock of carbon per unit of forestland. ${ }^{6}$ The forestry model's projections for annualized sequestration at the intensive margin at each carbon price in the first 20 years are reported in the second column of Table $5 .^{7}$ Overall, there is

\footnotetext{
${ }^{6}$ The aging component is estimated by comparing the carbon that accrues in forests under the particular carbon price scenario examined versus the carbon that would have accrued in the carbon price scenario timberland area (and management intensity) if managed with the baseline age classes. The algorithm used to calculate carbon due to aging does not distinguish between old and new hectares. Thus, if hectares newly forested in the mitigation scenario are eventually harvested in an age class older than the baseline age class, the carbon associated with longer rotations are counted as aging rather than as part of the afforestation component. This type of interaction between the extensive and intensive margins can give rise to negative contributions to sequestration at very low carbon prices (see the USA entry for \$5/TCE in Table 5). The management component is estimated by comparing the carbon sequestered under the carbon price scenario to the carbon sequestered assuming the carbon price scenario forest area and age classes are managed with the baseline management intensities.

${ }^{7}$ Extending this horizon further would increase the potential for sequestration as longer term adjustments would be taken into account.
} 
substantial potential for increasing the forest carbon stock at the intensive marginparticularly in the range of carbon prices of interest in this paper, up to \$100/TCE. ${ }^{8}$

The USA estimates in Table 5 are consistent with a recent detailed national assessment of U.S. mitigation potential in forestry and agriculture, which suggests that for \$55/TCE, up to 88.8 MMTCE per year could be sequestered in U.S. forests (Murray et al., 2005). According to Table 5, the USA and China could provide about $13 \%$ of global potential sequestration over the next 20 years. This, at first glance, is a surprisingly large proportion of the total carbon given that these countries contain only about $10 \%$ of the world's total forestland. The bulk of this sequestration in USA and China comes at the intensive margin and is attributable to changes in forest management aimed at increasing carbon stocks.

We calibrate the GTAP-AEZ-GHG model to Table 5 by implementing a forest sequestration subsidy with the model running in a partial equilibrium mode, with output levels and input prices fixed. The subsidy is applied to an augmented regional land input that includes two components: composite forest land (aggregated land from all AEZs used in the country's forestry production) and the own-use of forestry products in the forestry sector, which can be thought of as representing the volume of forest biomass on a given amount of forest land. Forest land area and forest biomass volume are allowed to substitute in production with an elasticity of substitution denoted by $\sigma_{\text {carbon }}$. While such a grouping of inputs may not appear intuitive at first glance, it works well to mimic the two

\footnotetext{
${ }^{8}$ The global timber model also estimates changes in carbon storage in wood products and forests set aside at the accessible/inaccessible margin in temperate and boreal regions. We ignore these factors. The two factors which account for only a very small portion of total carbon sequestration and their omission is unlikely to change our findings. Wood products could be accounted for in our framework, since we do follow wood products through markets and eventually to consumers. However, we have not yet estimated the carbon content of these flows and the associated stocks in our model.
} 
margins along which forest carbon can be increased — the intensive margin (modified management and aging) and the extensive margin (more land in forests).

We perform two calibrations. First, we assume that $\sigma_{\text {carbon }}=0$. In this case, the effect of the sequestration subsidy will be to increase the profitability of forestry with current management practices, thereby leading to an expansion of forest land with constant carbon intensity. This is the extensive margin and we calibrate to it by adjusting the incremental annual carbon intensity of forests. The calibrated values of these intensities are reported in Table 3. The higher the forest carbon intensity, the stronger the profitability and land area response to the sequestration subsidy. The intensity is larger in ROW than in China and USA, therefore advantaging ROW in the matter of forest carbon sequestration, i.e. a given per unit sequestration subsidy will have a greater ad valorem impact in the ROW region.

Next, we calibrate the intensive margin. To do so, we fix the total land in forestry, thereby eliminating the extensive margin altogether, and introduce $\sigma_{\text {carbon }}>0$ (once again running the model in partial equilibrium mode to mimic the assumptions made in Sohngen and Mendelsohn, 2007). In this case, the subsidy encourages an increase in the carbon intensity of forestry. In our model, this is reflected as a substitution of own-use of forest products, in the forestry sector, for forest land. This reduces net forestry output (net output is gross output produced less own-use), and thereby increasing the carbon intensity of production per unit of output. In effect, the forestry sector would choose to sacrifice some sales of commercial timber by adopting production practices that increase the carbon content on existing forest land. This intensive margin is calibrated by adjusting $\sigma_{\text {carbon }}$ until the GTAP-AEZ-GHG model replicates the carbon sequestration 
response from the global timber model. The fitted values of $\sigma_{\text {carbon }}$ are reported in the final column of Table 4. We find that this formulation of the GTAP-AEZ-GHG model permits us to replicate abatement costs from the dynamic timber model quite well for subsidies up to $\$ 100 /$ TCE.

\section{Results}

Having calibrated the GTAP-AEZ-GHG model to a suite of partial equilibrium GHG abatement costs, we now deploy our CGE model to investigate the market interactions between these different abatement opportunities. We summarize these interactions with general equilibrium GHG abatement supply schedules by region and sector, and then analyze the details within and between sectors regionally and globally. We also briefly consider regional versus global carbon policies. The general equilibrium supply schedules are derived by varying the per unit carbon tax incrementally from \$1/TCE to \$100/TCE.

Impacts of a Global Carbon Tax: Figure 1a portrays the global abatement supply, taking into account full general equilibrium adjustments. Here, we see that forestry and agriculture could provide emission reductions of up to 3.0 BTCE per year in the near term. The largest share of global abatement is from the extensive margin of forestry, which may be seen as the difference between the forestry total abatement curve in Figure 1a and the intensification curve. Most of this abatement is due to reduced emissions through avoided deforestation in tropical regions. Avoiding deforestation has a relatively large immediate impact on carbon emissions as large quantities of in situ carbon are preserved. Figure 1b offers a closer look at the results for the global agricultural sectors, 
where the ruminants sector offers the greatest abatement potential, followed by other crops.

For ease of exposition, we focus our discussion on the highest tax level shown in Figures 1a and 1b: \$100/TCE. Table 6 decomposes the global abatement at this price by region (columns) and type - fertilizer, paddy rice, ruminant livestock, miscellaneous agriculture and forest sequestration (rows) ${ }^{9}$ The change in total emissions for a \$100/TCE global tax is largest in ROW, followed by China and USA-- where abatement levels are quite similar. In all regions, forest sequestration provides the largest proportion of the total emissions reductions. Reductions in emissions from fertilizer use in US and from paddy rice in China are the second largest abatement activities, whereas ruminant livestock related emissions are the second largest individual source of abatement in ROW. Reducing emissions from rice paddies are also important in ROW.

These results indicate that forest carbon sequestration plays an important role in the global land use emissions abatement. As noted previously, in our modeling approach, the forest margin is broken into intensification and extensification. The latter dominates the near term story in the ROW region, accounting for most of the abatement (recall Figure 1a). However, sequestration attainable from intensification efforts in ROW is still quite large, around 400 MMTCE per year for \$50 - \$100/TCE, but this is only about 20\% of total potential abatement in ROW (Table 5). The results for ROW are heavily driven by efforts to reduce deforestation. Intensification is a more significant part of the story in

\footnotetext{
${ }^{9}$ The decomposition of global emissions by sector or emissions type utilizes the numerical integration technique proposed by Harrison, Horridge and Pearson (2000, henceforth HHP) to apportion the impact of each group of instruments on total emissions in each region or in the world. This has the virtue of producing individual estimates that add to the grand total. This would not be the case if the simulations were conducted separately, due to interaction effects.
} 
the U.S., accounting for nearly all of the abatement at low carbon prices (e.g., < \$20/TCE), and more than 50\% through carbon prices of \$100/TCE (Table 5).

Carbon sequestration through forest extensification has two different effects on emissions from agriculture. On the one hand, forest extensification bids land away from agriculture production, thereby reducing output and hence emissions - particularly of those GHG emissions linked to land use. On the other hand, it encourages more intensive production on the remaining land in agriculture, which can drive up GHG emissions from any particular hectare. In a separate simulation of the forest sequestration subsidy alone, we have ascertained that the former effect dominates, so that forest extensification (reductions in agricultural land due to expansion of forests) reduces overall agriculture emissions when forest sequestration occurs.

Changes in Agricultural Factor Intensities and Output: Table 7 reports the percentage changes agricultural outputs and for selected input-output intensities (land, labor and fertilizer) in the three regions. We see that some of the largest changes in input intensities are for fertilizer use in US crop production, where the emissions intensity is quite high (recall Table 3), and land use in paddy rice production in all three regions. These are directly related to the emissions taxes which fall on these inputs. In each case, the scope for emissions reduction has been determined based on detailed analyses (USEPA, 2006b), which in turn are embedded in the calibration of the production functions (Table 4). In order to reduce fertilizer usage in US corn production, for example, farmers use more of other inputs. Thus labor usage per bushel of corn rises by $8 \%$, while other variable input intensities rise by even more. 
Of course total emissions in any of these sectors depend, not just on input-output intensities, but on total output. The first column in Table 7 reports the changes in output in these land-using agricultural sectors. Agricultural output in USA agricultural sectors rises, as the emissions tax scenario favors USA farming. The largest output increase occurs in USA paddy rice and amounts to $13 \%$ in the wake of rising world prices due to declining output in China and ROW. However, this increase is attained through higher yields, and not increased land area. In contrast, agricultural output in ROW falls in all of the land-using sectors, as forestry area expands in response to the sequestration subsidy. Of course, in practice, much of the loss in ROW agricultural area will actually be forgone deforestation. So these should be viewed as changes relative to baseline. In China, there are declines in all these sectors as well, with the largest output reductions arising in the cases of paddy rice and ruminant livestock production, where China's emissions intensities are relatively large (Table 3).

Changes in Land Use: Having seen that competition for land - particularly between forestry and agriculture - plays an important role in determining the global change in output following a $\$ 100 /$ TCE emissions tax, it is worthwhile to investigate changes in the land market in more detail. We do this in Table 8 for USA and China. Note that the nested CET transformation function does not model a constraint on total physical hectares in a given AEZ, but rather preserves the sum of productivity-shareweighted hectares within each AEZ, where productivity is based on observed land rents. Accordingly, we report the land quantity changes in these terms, where the weights are the share of total land rents in a given AEZ, generated by a particular activity. Since they 
are share-weighted, the entries in Table 8 should be interpreted as percentage changes, relative to the annual flow of economic value associated with total land in a given AEZ.

Table 8 reports that expanding forestry production in the USA absorbs more than 7 percent of the land endowment in AEZ 12. The bulk of this comes from Other Crops, but all of the agricultural sectors give up some land in AEZ12 to permit this expansion of high productivity land into forestry in response to the sequestration subsidy. In AEZ11, there is a similar percentage expansion in forestry, but now two-thirds of it comes from grains production, since the mix of economic activities varies by AEZ. Land area devoted to Other Crops production, which is not sharply affected by the emissions tax, expands in those AEZs where commercial forestry is not a significant activity. On the other hand, land devoted to ruminant livestock production shrinks across the board.

Forestry expands in all AEZs in all regions. The largest rental share-weighted increases are in ROW (not shown), where the expansion is on the order of $12 \%$ in the more productive tropical and temperate AEZs. Forestry expansion in China is more modest, when weighted by its share in total land rents. There, land area in paddy rice and ruminants falls in all AEZs, with the land often being absorbed by the Other Crops and Other Grains sectors.

Changes in Global Competitiveness: Table 9 reports the change in regional trade balances due to a global carbon tax of \$100/TCE in agricultural sectors and forestry. From these results we see that the carbon tax changes the pattern of global competitiveness. The dramatic expansion of forest lands in ROW squeezes the amount of land available for crops and grazing. Thus, ROW shows a deterioration in its trade balance for all other land using sectors. Of course, ROW must somehow pay for these 
increased imports and they do so largely with increased exports of forest products, as well as manufactures and services.

The USA, on the other hand, benefits from its lower emissions intensities in rice and livestock production, strongly expanding net exports of these products. In the case of other grains production, USA has high emissions intensity (recall Table 3). However, this does not stop the USA from expanding net exports of crops to ROW, in the wake of the reduction in crop area in that region. The only land-using sector where China strongly increases net exports is Other Crops, where it has a lower emissions intensity than USA (Table 3) and substantial export potential due to low wages in labor intensive sectors (e.g., fruits and vegetables).

Unilateral vs. Global Abatement Costs: An important aspect of climate policy relates to how well countries coordinate their actions. Carbon price differences across regions could distort markets. It is therefore useful to assess how the general equilibrium abatement supply changes depending on assumptions regarding regional carbon policies. Analysis is frequently conducted on a country-by-country basis, implicitly assuming that other countries do not have carbon policies (e.g, Murray et al., 2005, for the USA). ${ }^{10}$ To explore these issues, we construct a simple example, beginning with the global carbon tax policy described above. The general equilibrium abatement supply for the two forestry options (intensification and extensification) and the agricultural sector, resulting from a global carbon tax reveals that, at \$100/TCE, US abatement reaches a maximum of 225

\footnotetext{
${ }^{10}$ While many other features of the two studies differ, it is also instructive to compare our results directly to those of Murray et al. (2005), who find that approximately 8 MMTCE of CH4 and NO2 emissions can be abated in the agricultural sector annually, from 2010-2019, and about 101 MMTCE per year can be sequestered in the forestry sector for \$55/TCE. In our study, at \$55/TCE, 10 MMTCE can be abated in the agricultural sector under the global coordinated tax, and 20 MMTCE can be abated each year under the USA only tax. For forest sequestration, around 110 MMTCE can be sequestered under the global coordinated tax and 120 MMTCE under the USA only tax.
} 
MMTCE, with a 42 MMTCE reduction derived from the agricultural sector and 183 MMTCE through forest sequestration. Now contrast this with the case where abatement is implemented in USA alone. In this case, at \$100/TCE, US abatement reaches a maximum of 236 MMTCE - about 5 percent more abatement for the same carbon price, with around 180 MMTCE obtained from forest sequestration and 56 MMTCE from agriculture emissions. In agriculture, USA abatement is diminished by $25 \%$ under the global tax compared to the USA only tax, while in forestry there is a slight increase. These results illustrate important global market effects. The domestic carbon tax increases the cost of USA agricultural products relative to international production. As a result, international production increases, as does GHG emissions. On the other hand, when the tax is applied globally, USA agriculture has a comparative production advantage and GHG abatement in agriculture becomes more expensive as the opportunity cost of mitigation increases. In short, differential regional carbon prices can affect the marginal abatement of each region. Studies that only examine national carbon policies, and do not consider the relative effects of regional carbon policies, could significantly mis-estimate the extent of abatement in agriculture and forestry.

\section{Conclusions}

We have developed a computable general equilibrium model with unique regional land types and detailed non- $\mathrm{CO}_{2}$ GHG emissions, with emphasis placed on land-based greenhouse gas emissions and forest sequestration. The GTAP-AEZ-GHG model is augmented with information from two partial equilibrium approaches. For agricultural mitigation of GHGs we calibrate our model based on mitigation possibilities derived from detailed engineering and agronomic studies developed by the US Environmental 
Protection Agency. In the case of forest carbon sequestration, we draw on estimates of optimal sequestration responses to global forest carbon subsidies, derived from the model used in Sohngen and Mendelsohn (2007).

Using this framework, we estimate general equilibrium abatement supply for non$\mathrm{CO}_{2}$ mitigation in agriculture and for forest carbon sequestration. We find that at \$100/TCE, abatement in agriculture and forestry could be as large as 3.0 billion TCE per year over the next 20 years. Biophysical and economic characteristics, however, are shown to have important influences on the comparative abatement advantage of GHG mitigation across sectors within a given country, and between the same sectors in different countries. Of course, there are uncertainties in inventories of methane, N2O, and historic land carbon storage and fluxes. Nonetheless, while the specific numbers may change, the general conclusions of the paper are expected to be robust.

In our results, forest carbon sequestration is found to have the lowest marginal costs for global GHG emissions reduction in the land using sectors, accounting for around $87 \%$ of total abatement at $\$ 100 /$ TCE. When compared to the rest of the world, emissions abatement in the US and China comes disproportionately from agriculture, and, within agriculture, disproportionately from reductions in fertilizer-related emissions. In the world as a whole, agriculture-related mitigation comes predominantly from reduced methane emissions from ruminant livestock, which is followed in relative importance by reductions in fertilizer use and then methane emissions from paddy rice.

A comparison of carbon tax policies implemented globally and then only in the USA shows the importance of this general equilibrium and global analysis. For agriculture in the USA, abatement potential is diminished by 25 percent when we move 
from a USA-only carbon tax to a global carbon tax. This is a consequence of the strong export orientation of US agriculture, which responds to reduced production in the rest of the world by increasing its own production and hence emissions. These results imply that national level analyses for the U.S. could under-estimate the costs of emissions abatement because they do not account for the implications of price changes that occur elsewhere in the world.

Forestry sequestration is broken into intensification (increased carbon per hectare) and extensification (increased forest hectares). The results show that intensification has significant mitigation potential in all regions. The potential is relatively larger in the USA and China in this analysis, which is intuitive given the substantial experience with managing timber in those regions. Forest extensification has the largest abatement potential in the ROW region. Over the next 20 years, ROW extensification largely means a reduction in deforestation. Interestingly, in our model, extensification has a positive feedback effect to the agricultural sector, as more land is maintained in forests rather than converted to agriculture and overall emissions in the agricultural sector decline.

A natural extension of this work is to integrate the analysis of non-CO2 emissions and carbon forest sequestration with the more conventional analyses of $\mathrm{CO} 2$ emissions from fossil fuel combustion and industrial sources. The latter have been extensively analyzed in global general equilibrium models. The approach outlined in this paper will allow for more structured and rigorous consideration of the trade-offs between these two broad types of mitigation options. Preliminary simulations with our model, augmented with CO2 emissions from fossil fuel combustion, suggest that, at \$100/TCE, the mitigation analyzed in this paper would amount to nearly one-quarter of the emissions 
reduction obtained through a tax on fossil fuels alone, with the contribution varying significantly across regions. In this context, one could also model and assess the complex relationships between land and energy markets associated with biofuels and bioelectricity, which simultaneously modify the opportunity costs of alternative land-use and energy feedstocks. The magnitude of the preliminary result further motivates the need for comprehensive economic assessments of GHG mitigation that explicitly capture the heterogeneous opportunity costs of land-based mitigation. 


\section{References}

Ahammad, H. (2006). “Modeling Land Use Change \& Emissions in GTEM”, presented at the EMF-22 Land-use and Black Carbon Modeling Workshop, Washington, DC. February 1-3, 2006.

Choi, S. (2004). "The Potential and Cost of Carbon Sequestration in Agricultural Soil: An Empirical Study with a Dynamic Model for the Midwestern U.S." Ph.D. Thesis. Department of Agricultural, Environmental, and Development Economics, Ohio State University.

de la Chesnaye, F.C. and J.P Weyant, (eds.), 2006: Multigas Mitigation and Climate Policy. The Energy Journal Special Issue \#3.

Darwin, R., M. Tsigas, J. Lewandrowski and A. Raneses (1995). World Agriculture and Climate Change: Economic Adaptations, Agricultural Economic Report \#703, Washington, D.C.: USDA.

Darwin, R., Tsigas, M., Lewandrowski, J., Raneses, A., 1996. Land use and cover in ecological economics. Ecological Economics 17, 157-181.

Dimaranan, B. V., Edt. (2006, forthcoming). Global Trade, Assistance, and Production: The GTAP 6 Data Base, Center for Global Trade Analysis, Purdue University, West Lafayette, IN47907, U.S.A.

Eickhout, B., H. van Meijl and A. Tabeau, (2008). "The impact of Environmental and Climate Constraints on Global Food Supply”, In Economic Analysis of Land Use in Global Climate Change Policy. Edited by T. Hertel, S. Rose and R. Tol. Routledge: forthcoming.

FAO and IIASA. (2000). Global Agro-Ecological Zones - 2000. Food and Agriculture Organization (FAO) of the United Nations, Rome, Italy, and International Institute for Applied Systems Analysis (IIASA), Laxenburg, Austria.

Fawcett, A.A., and R.D. Sands, 2006. Non-CO2 Greenhouse Gases in the Second Generation Model. Multigas Mitigation and Climate Policy. The Energy Journal Special Issue \#3.

Harrison, J., Horridge, M. and Pearson, K.R., 2000. Decomposing simulation results with respect to exogenous shocks. Computational Economics, 15(3), 227-249.

Houghton, R.A., 2003. "Revised estimates of the annual net flux of carbon to the atmosphere from changes in land use and land management: 1850-2000”, Tellus Series B-Chemical and Physical Meteorology, 55 (2), 378-390.

Hourcade, J.-C., Shukla, P.R., Cifuentes, L., Davis, D., Emonds, J., Fisher, B., Fortin, E., Golub, A., Hohmeyer, O., Krupnick, A., Kverndokk, S., Loulou, R., Richels, R., 
Segenovic, H., Yamaji, K., (2001). "Global, Regional, and National Costs and Ancillary Benefits of Mitigation,” Chapter 8 in Climate Change 2001: Mitigation Contribution of Working Group III to the Third Assessment Report of the Intergovernmental Panel on Climate Change, Cambridge University Press, Cambridge, pp. 702.

Hyman, R.C., J.M. Reilly, M.H. Babiker, A. de Masin and H.D. Jacoby, 2003. Modeling Non-CO2 Greenhouse Gas Abatement. Environmental Modeling and Assessment, 8: 175-186.

Ianchovichina, E., R. Darwin, and R. Shoemaker (2001). Resource use and technological progress in agriculture: a dynamic general equilibrium analysis. Ecological Economics, 38: 275-291.

IPCC. (1996). Climate Change 1995: The Science of Climate Change. Intergovernmental Panel on Climate Change (IPCC) Cambridge University Press, Cambridge, United Kingdom.

IPCC. (2001a). Climate Change 2001: Mitigation. Contribution of Working Group III to the Third Assessment Report (TAR) of the Intergovernmental Panel on Climate Change (IPCC). B. Metz, O. Davidson, R. Swart, and J. Pan (eds.). Cambridge University Press, U.K. 700 pp.

IPCC. (2001b). Climate Change 2001: A Scientific Basis. Intergovernmental Panel on Climate Change (IPCC). J. T. Houghton, Y. Ding, D. J. Griggs, M. Noguer, P. J. van der Linden, X. Dai, C. A. Johnson, and K. Maskell (eds.). Cambridge University Press, Cambridge, U.K.

Keeney, R., and T.W. Hertel, 2005. GTAP-AGR: A Framework for Assessing the Implications of Multilateral Changes in Agricultural Policies. GTAP Technical Paper 24, Center for Global Trade Analysis, available on line at www.gtap.org.

Klepper, G. and S. Peterson, 2006. "Marginal Abatement Cost Curves in General Equilibrium: The Influence of World Energy Prices," Resource and Energy Economics, 28(1):1-23.

Lee, H.-L., 2004. "Incorporating Agro-ecologically Zoned Data into the GTAP Framework”, paper presented at the Seventh Annual Conference on Global Economic Analysis, The World Bank, Washington, D.C., June.

Lee, H.-L., T. W. Hertel, S. Rose and M. Avetisyan (2008) "An Integrated Global Land Use Data Base for CGE Analysis of Climate Change Policy Options," Chapter 4 in Hertel, T.W., S. Rose and R. Tol (eds.) Economic Analysis of Land Use in Global Climate Policy, Routledge (forthcoming). 
Li, C., W. Salas, B. DeAngelo, and S. Rose, 2006. “Assessing Alternatives for Mitigating Net Greenhouse Gas Emissions and Increasing Yields from Rice Production in China Over the Next 20 Years,” Journal of Environmental Quality 35(4).

McCarl, B. and R. Sands, 2007. "Competitiveness of terrestrial greenhouse gas offsets: are they a bridge to the future?” Climatic Change Volume 80, Numbers 1-2, pp 109-126.

Murray, B.C., B.L. Sohngen, A.J. Sommer, B.M. Depro, K.M. Jones, B.A. McCarl, D. Gillig, B. DeAngelo, and K. Andrasko. 2005. EPA-R-05-006. "Greenhouse Gas Mitigation Potential in U.S. Forestry and Agriculture." Washington, D.C: U.S. Environmental Protection Agency, Office of Atmospheric Programs.

Olivier, J.G.J., 2002. Part III: Greenhouse gas emissions: 1. Shares and trends in greenhouse gas emissions; 2. Sources and Methods; Greenhouse gas emissions for 1990 and 1995. In: "CO2 emissions from fuel combustion 1971-2000", 2002 Edition, pp. III.1-III.31. International Energy Agency (IEA), Paris. ISBN 92-64-09794-5.

Organization for Economic Cooperation and Development. (2001). Market Effects of Crop Support Measures, OECD Publications, Paris, France.

Reilly, J., M. Sarofim, S. Paltsev, and R. Prinn, 2006. The role of non- CO2 GHGs in climate policy: analysis using the MIT IGSM. Multigas Mitigation and Climate Policy. The Energy Journal Special Issue \#3.

Richards, K., and C. Stokes, 2004. “A Review of Forest Carbon Sequestration Cost Studies: A Dozen Years of Research”, Climatic Change, 63 (1-2), 1-48.

Rokityanskiy, Dmitry, Pablo Benitez, Florian Kraxner, Ian McCallum, Michael Obersteiner, Ewald Rametsteiner, and Yoshiki Yamagata, 2006: Geographically explicit global modeling of land-use change, carbon sequestration and biomass supply. Special Issue of Technological Forecasting and Social Change.

Rose, S., H. Ahammad, B. Eickhout, B. Fisher, A. Kurosawa, S. Rao, K. Riahi, and D. van Vuuren, 2006a. "Land in climate stabilization modeling,” Energy Modeling Forum Report, Stanford University, http://www.stanford.edu/group/EMF/home/index.htm

Rose, S., S. Finn, E. Scheele, J. Mangino, and K. Delhotal, 2006b. “Detailed greenhouse gas emissions data for global economic modeling”, US Environmental Protection Agency, Washington, DC.

Rose, S. and Lee, H.L. (2008) "Non-CO2 Greenhouse Gas Emissions Data for Climate Change Economic Analysis,” Chapter 5 in Hertel, T.W., S. Rose and R. Tol (eds.) Economic Analysis of Land Use in Global Climate Policy, Routledge (forthcoming).

Rosegrant, M.W., M.S. Paisner, S. Meijer, and J. Witcover, 2001. Global Food Projections to 2020: Emerging Trends and Alternative Futures, International Food Policy Research Institute, pp 206. 
Sands, Ronald D. and Marian Leimbach, 2003. "Modeling Agriculture and Land Use in Integrated Assessment Framework,” Climatic Change 56: 185-210.

Sohngen, B. and S. Brown. 2006. "The Influence of Conversion of Forest Types on Carbon Sequestration and other Ecosystem Services in the South Central United States." Ecological Economics. 57: 698-708.

Sohngen, B. and R. Sedjo. 2000. "Potential Carbon Flux from Timber Harvests and Management in the Context of a Global Timber Market." Climatic Change. 44: 151172.

Sohngen, B., R. Mendelsohn, and R. Sedjo. 2001. "A Global Model of Climate Change Impacts on Timber Markets." Journal of Agricultural and Resource Economics. 26(2): 326-343.

Sohngen, B. and R. Mendelsohn. 2003. “An Optimal Control Model of Forest Carbon Sequestration” American Journal of Agricultural Economics. 85(2): 448-457.

Sohngen, B. and R. Mendelsohn. 2007. "A Sensitivity Analysis of Carbon Sequestration." In Human-Induced Climate Change: An Interdisciplinary Assessment. Edited by M. Schlesinger. Cambridge University Press.

Sohngen, B and R. Sedjo. 2006. "Carbon Sequestration Costs in Global Forests." Forthcoming: Energy Journal.

Sohngen, B., C. Tennity, M. Hnytka and K. Meeusen, 2008. “Global Forestry Data for the Economic Modeling of Land Use” in Thomas W. Hertel, Steven Rose, Richard Tol (eds.), Economic Analysis of Land Use in Global Climate Change Policy, Routledge Publishing.

USEPA, 2006a. Global Emissions of Non-CO2 Greenhouse Gases: 1990-2020. Office of Air and Radiation, US Environmental Protection Agency (US-EPA), Washington, D.C.

USEPA, 2006b. Global Mitigation of Non-CO2 Greenhouse Gases. United States Environmental Protection Agency, Washington, DC, 430-R-06-005, http://www.epa.gov/nonco2/econ-inv/international.html

van Vuuren, D.P., B. Eickhout, P.L. Lucas and M.G.J. den Elzen, 2006-a: Long-term multi-gas scenarios to stabilise radiative forcing: exploring costs and benefits within an integrated assessment framework. Multigas Mitigation and Climate Policy. The Energy Journal Special Issue \#3. 
Table 1. Land rents at market price by AEZ and sector for the USA and China (million 2001 US\$)

\begin{tabular}{|c|c|c|c|c|c|c|c|c|c|c|}
\hline \multirow{2}{*}{$\begin{array}{c}\text { Agro- } \\
\text { Ecological } \\
\text { Zones } \\
\end{array}$} & \multicolumn{5}{|c|}{ USA } & \multicolumn{5}{|c|}{ China } \\
\hline & Paddy rice & $\begin{array}{l}\text { Other } \\
\text { grains }\end{array}$ & $\begin{array}{l}\text { Other } \\
\text { crops }\end{array}$ & Ruminants & Forestry & Paddy rice & $\begin{array}{l}\text { Other } \\
\text { grain }\end{array}$ & $\begin{array}{l}\text { Other } \\
\text { crops }\end{array}$ & Ruminants & Forestry \\
\hline \multicolumn{11}{|l|}{ Tropical } \\
\hline AEZ1 & 0 & 0 & 0 & 0 & 0 & 0 & 0 & 0 & 0 & 0 \\
\hline AEZ2 & 0 & 0 & 0 & 0 & 0 & 0 & 0 & 0 & 0 & 0 \\
\hline AEZ3 & 0 & 0 & 0 & 0 & 0 & 0 & 0 & 0 & 0 & 0 \\
\hline AEZ4 & 0 & 0 & 0 & 0 & 0 & 4 & 1 & 40 & 1 & 0 \\
\hline AEZ5 & 0 & 0 & 0 & 0 & 0 & 10 & 3 & 92 & 1 & 0 \\
\hline AEZ6 & 0 & 0 & 0 & 0 & 0 & 250 & 60 & 2464 & 13 & 433 \\
\hline \multicolumn{11}{|l|}{ Temperate } \\
\hline AEZ7 & 0 & 1951 & 3435 & 3359 & 0 & 15 & 136 & 551 & 498 & 0 \\
\hline AEZ8 & 0 & 2087 & 2877 & 784 & 0 & 95 & 861 & 3395 & 458 & 100 \\
\hline AEZ9 & 17 & 1926 & 2016 & 146 & 0 & 183 & 1376 & 5361 & 146 & 220 \\
\hline AEZ10 & 116 & 7503 & 5304 & 494 & 209 & 170 & 730 & 3102 & 83 & 296 \\
\hline AEZ11 & 228 & 4346 & 2449 & 309 & 627 & 957 & 972 & 5175 & 126 & 780 \\
\hline AEZ12 & 158 & 1069 & 1951 & 155 & 4392 & 3047 & 873 & 13415 & 234 & 4941 \\
\hline \multicolumn{11}{|l|}{ Boreal } \\
\hline AEZ13 & 0 & 57 & 99 & 88 & 0 & 1 & 29 & 98 & 343 & 0 \\
\hline AEZ14 & 0 & 13 & 28 & 30 & 0 & 0 & 17 & 31 & 267 & 0 \\
\hline AEZ15 & 0 & 2 & 7 & 2 & 0 & 11 & 43 & 65 & 302 & 46 \\
\hline AEZ16 & 0 & 0 & 1 & 0 & 0 & 3 & 11 & 34 & 43 & 3 \\
\hline AEZ17 & 0 & 0 & 0 & 0 & 0 & 0 & 1 & 1 & 1 & 0 \\
\hline AEZ18 & 0 & 0 & 0 & 0 & 0 & 0 & 0 & 0 & 0 & 0 \\
\hline
\end{tabular}


Table 2. Non- $\mathrm{CO}_{2}$ GHG emissions by agricultural sector and emissions source (MMTCE)

\begin{tabular}{|c|c|c|c|c|c|c|c|c|c|c|c|}
\hline & \multicolumn{10}{|c|}{ Emissions sources } & \multirow[b]{3}{*}{ Total } \\
\hline & \multicolumn{5}{|c|}{ Methane $\left(\mathrm{CH}_{4}\right)$} & \multicolumn{5}{|c|}{ Nitrous oxide $\left(\mathrm{N}_{2} \mathrm{O}\right)$} & \\
\hline & $\begin{array}{c}\text { Enteric } \\
\text { fermentation }\end{array}$ & $\begin{array}{c}\text { Manure } \\
\text { management }\end{array}$ & $\begin{array}{c}\text { Rice } \\
\text { cultivation }\end{array}$ & $\begin{array}{l}\text { Biomass } \\
\text { burning }\end{array}$ & $\begin{array}{l}\text { Stationary } \\
\text { and mobile } \\
\text { combustion }\end{array}$ & $\begin{array}{c}\text { Agricultural } \\
\text { soils }\end{array}$ & $\begin{array}{c}\text { Manure } \\
\text { management }\end{array}$ & $\begin{array}{l}\text { Pasture, } \\
\text { range, } \\
\text { and } \\
\text { paddock }\end{array}$ & $\begin{array}{r}\text { Biomass } \\
\text { burning }\end{array}$ & $\begin{array}{l}\text { Stationary } \\
\text { and mobile } \\
\text { combustion }\end{array}$ & \\
\hline \multicolumn{12}{|l|}{ U.S.A. } \\
\hline $\begin{array}{l}\text { Paddy } \\
\text { Rice }\end{array}$ & 0 & 0 & 2.051 & 0.003 & 0.001 & 0.914 & 0 & 0 & 0.002 & 0 & 2.971 \\
\hline $\begin{array}{l}\text { Other } \\
\text { Grain }\end{array}$ & 0 & 0 & 0 & 0.085 & 0.012 & 37.557 & 0 & 0 & 0.05 & 0.004 & 37.707 \\
\hline $\begin{array}{l}\text { Other } \\
\text { Crops }\end{array}$ & 0 & 0 & 0 & 0.129 & 0.013 & 23.485 & 0 & 0 & 0.075 & 0.004 & 23.707 \\
\hline Ruminants & 30.869 & 5.058 & 0 & 0 & 0.005 & 0 & 2.913 & 9.932 & 0 & 0.001 & 48.778 \\
\hline $\begin{array}{l}\text { Non- } \\
\text { Ruminants }\end{array}$ & 0.51 & 5.388 & 0 & 0 & 0.005 & 0 & 1.922 & 0.078 & 0 & 0.002 & 7.904 \\
\hline Total & & & & & & & & & & & 121.067 \\
\hline \multicolumn{12}{|l|}{ China } \\
\hline $\begin{array}{l}\text { Paddy } \\
\text { Rice }\end{array}$ & 0 & 0 & 59.33 & 0 & 0.005 & 10.822 & 0 & 0 & 0 & 0.004 & 70.16 \\
\hline $\begin{array}{l}\text { Other } \\
\text { Grain }\end{array}$ & 0 & 0 & 0 & 0 & 0.01 & 20.267 & 0 & 0 & 0 & 0.007 & 20.284 \\
\hline $\begin{array}{l}\text { Other } \\
\text { Crops }\end{array}$ & 0 & 0 & 0 & 0 & 0.037 & 77.847 & 0 & 0 & 0 & 0.027 & 77.911 \\
\hline Ruminants & 51.901 & 2.089 & 0 & 0.219 & 0.002 & 0 & 5.444 & 9.067 & 0.048 & 0.002 & 68.773 \\
\hline $\begin{array}{l}\text { Non- } \\
\text { Ruminants }\end{array}$ & 2.981 & 4.577 & 0 & 0 & 0.028 & 0 & 11.928 & 22.351 & 0 & 0.02 & 41.884 \\
\hline Total & & & & & & & & & & & 279.012 \\
\hline \multicolumn{12}{|l|}{ ROW } \\
\hline $\begin{array}{l}\text { Paddy } \\
\text { Rice }\end{array}$ & 0 & 0 & 107.957 & 0.437 & 0.016 & 28.783 & 0 & 0 & 0.159 & 0.012 & 137.364 \\
\hline $\begin{array}{l}\text { Other } \\
\text { Grain }\end{array}$ & 0 & 0 & 0 & 1.136 & 0.095 & 99.65 & 0 & 0 & 0.413 & 0.069 & 101.363 \\
\hline $\begin{array}{l}\text { Other } \\
\text { Crops }\end{array}$ & 0 & 0 & 0 & 2.862 & 0.244 & 162.894 & 0 & 0 & 1.04 & 0.179 & 167.219 \\
\hline Ruminants & 380.44 & 25.968 & 0 & 52.962 & 0.071 & 0 & 17.671 & 141.256 & 11.711 & 0.052 & 630.131 \\
\hline $\begin{array}{l}\text { Non- } \\
\text { Ruminants }\end{array}$ & 2.985 & 21.337 & 0 & 0 & 0.048 & 0 & 14.115 & 41.07 & 0 & 0.035 & 79.59 \\
\hline Total & & & & & & & & & & & 1115.667 \\
\hline World Tota & al for Agricul & tural Sectors & & & & & & & & & 1515.746 \\
\hline
\end{tabular}


Table 3. Key initial emission intensities ( $\mathrm{MtC} / \$$ of input, where $\mathrm{MtC}=1000 \mathrm{Kg} \mathrm{C})$

\begin{tabular}{llll|lll}
\hline \multirow{2}{*}{ Emission intensities (MtC/\$ of input) } & & & & \multicolumn{3}{|l}{$\begin{array}{l}\text { Forest carbon intensities* } \\
\text { (MtC/ of land rent) }\end{array}$} \\
\hline Input & USA & China & ROW & USA & China & ROW \\
Fertilizer in crops production & 0.0062 & 0.0044 & 0.0044 & 0.058 & 0.017 & 0.134 \\
Ruminant livestock capital & 0.0096 & 0.1072 & 0.0149 & & & \\
Non ruminant livestock capital & 0.0021 & 0.0058 & 0.0036 & & & \\
Land in paddy rice & 0.0040 & 0.0125 & 0.0049 & & & \\
\hline
\end{tabular}

*Adjusted forest carbon intensities to calibrate to Sohngen and Mendelsohn (2007) forest carbon response curves.

Table 4. Elasticities of substitution: Shaded boxes denote elasticities calibrated for emissions mitigation and sequestration

\begin{tabular}{|c|c|c|c|c|c|c|c|}
\hline & & \multicolumn{6}{|c|}{ Sectors } \\
\hline & & Paddy rice & Other grain & Other crops & Ruminants & $\begin{array}{c}\text { Non- } \\
\text { ruminants }\end{array}$ & Forest \\
\hline \multirow{3}{*}{$\begin{array}{l}\text { Intermediate } \\
\text { inputs }\end{array}$} & USA & 0.80 & $0.80 *$ & 0.80 & 0.80 & 0.80 & $1.26 * *$ \\
\hline & China & 0.50 & $0.50 *$ & 0.50 & 0.50 & 0.50 & $1.80 * *$ \\
\hline & ROW & 0.51 & $0.73 *$ & 0.70 & 0.75 & 0.73 & $0.33 * *$ \\
\hline \multirow[t]{3}{*}{ Value added } & USA & 0.48 & 0.50 & 0.46 & 0.66 & 0.69 & 0.2 \\
\hline & China & 0.50 & 0.50 & 0.50 & 0.50 & 0.50 & 0.2 \\
\hline & ROW & 0.45 & 0.48 & 0.53 & 0.60 & 0.63 & 0.2 \\
\hline \multirow{3}{*}{$\begin{array}{l}\text { Capital and } \\
\text { capital related } \\
\text { emissions }\end{array}$} & USA & & & & & 0.043 & \\
\hline & China & & & & & 0.001 & \\
\hline & ROW & & & & & 0.030 & \\
\hline \multirow{3}{*}{$\begin{array}{l}\text { Land and land } \\
\text { related } \\
\text { emissions } \\
\end{array}$} & USA & $\mathrm{n} / \mathrm{a}$ & & & & & \\
\hline & China & 0.005 & & & & & \\
\hline & ROW & 0.026 & & & & & \\
\hline \multirow{3}{*}{$\begin{array}{l}\text { Output and } \\
\text { output related } \\
\text { emissions }\end{array}$} & USA & & & & 0.023 & & \\
\hline & China & & & & 0.015 & & \\
\hline & ROW & & & & 0.012 & & \\
\hline
\end{tabular}

* In the GE model, these econometrically estimated elasticities of substitution (OECD, 2001) provide abatement very close to one obtained in engineering studies.

* * Elasticity of substitution between own-use of forest products and land, $\sigma_{\text {carbon }}$, calibrated to reproduce the intensive sequestration response in forestry. 
Table 5. Carbon sequestration supply schedule: by category, annual equivalent abatement over 20 years (MMTCE)**

\begin{tabular}{|c|c|c|c|}
\hline Global Carbon price & Extensive Margin & Intensive Margin & Total \\
\hline \multicolumn{4}{|l|}{$\overline{\text { USA }}$} \\
\hline 5 & 1.672 & -1.663 & 0.009 \\
\hline 10 & 3.509 & 6.802 & 10.311 \\
\hline 20 & 7.023 & 24.585 & 31.608 \\
\hline 50 & 17.811 & 73.503 & 91.314 \\
\hline 100 & 43.069 & 102.749 & 145.818 \\
\hline 200 & 118.287 & 119.006 & 237.293 \\
\hline 500 & 270.741 & 286.616 & 557.357 \\
\hline \multicolumn{4}{|l|}{$\overline{\text { CHINA }}$} \\
\hline 5 & 0.44 & 3.018 & 3.458 \\
\hline 10 & 0.612 & 14.865 & 15.477 \\
\hline 20 & 1.21 & 26.899 & 28.109 \\
\hline 50 & 4.154 & 73.928 & 78.082 \\
\hline 100 & 12.797 & 98.522 & 111.319 \\
\hline 200 & 73.532 & 97.503 & 171.035 \\
\hline 500 & 108.663 & 202.142 & 310.805 \\
\hline \multicolumn{4}{|l|}{$\overline{\text { ROW }}$} \\
\hline 5 & 143.218 & 31.572 & 174.79 \\
\hline 10 & 281.67 & 78.626 & 360.296 \\
\hline 20 & 539.266 & 114.936 & 654.202 \\
\hline 50 & 1203.164 & 250.691 & 1453.855 \\
\hline 100 & 1672.509 & 387.619 & 2060.128 \\
\hline 200 & 2189.741 & 366.732 & 2556.473 \\
\hline 500 & 2885.44 & 868.723 & 3754.163 \\
\hline
\end{tabular}

** Storage due to setting aside of forests at accessible margin in temperate and boreal regions only 
Table 6. General equilibrium impact of emissions taxes on net emissions in each region following a global tax of \$100/TCE in agricultural sectors and forestry

\begin{tabular}{|c|c|c|c|c|}
\hline \multirow{2}{*}{ Type/region of taxation } & \multirow{2}{*}{ Global } & \multicolumn{3}{|c|}{ Emissions change from region (MMTCE) } \\
\hline & & USA & $\mathrm{CHN}$ & ROW \\
\hline Fertilizer & -78 & -16 & -14 & -48 \\
\hline $\begin{array}{l}\text { Land use related emissions in } \\
\text { paddy rice (methane) }\end{array}$ & -52 & 0 & -16 & -36 \\
\hline $\begin{array}{l}\text { Land and capital use related } \\
\text { emissions in ruminant livestock }\end{array}$ & -109 & -6 & -11 & -92 \\
\hline Miscellaneous & -166 & -20 & -49 & -97 \\
\hline Forest sequestration & -2621 & -183 & -169 & -2269 \\
\hline Total Impact & -3028 & -225 & -260 & -2543 \\
\hline
\end{tabular}

Table 7. Percentage changes in agricultural output levels and inputintensities following a \$100/TCE global carbon tax in agricultural sectors and forestry

\begin{tabular}{lcccc}
\hline & & \multicolumn{3}{c}{ Factor of Production } \\
\cline { 3 - 5 } & Output & Land & Labor & Fertilizer \\
\hline USA & & & & \\
Paddy Rice & 13 & -21 & 11 & -19 \\
Other Grains & 0.1 & -5 & 8 & -26 \\
Other Crops & 3 & -7 & 5 & -29 \\
Ruminants & 2 & -7 & 3 & \\
China & & & & \\
Paddy Rice & -7 & -19 & 17 & -3 \\
Other Grains & -2 & 1 & 7 & -11 \\
Other Crops & -1 & -1 & 6 & -12 \\
Ruminants & -8 & 4 & 7 & \\
ROW & & & & \\
Paddy Rice & -4 & -17 & 13 & -5 \\
Other Grains & -4 & -16 & 10 & -15 \\
Other Crops & -3 & -16 & 8 & -14 \\
Ruminants & -6 & -20 & 7 & \\
\hline
\end{tabular}


Table 8. Percentage changes in rental share weighted land use, by AEZ and sector in USA and China due to a \$100/TCE global carbon tax in land using sectors

\begin{tabular}{|c|c|c|c|c|c|}
\hline USA & Forestry & Paddy Rice & Other Grains & Other Crops & Ruminants \\
\hline AEZ1 - AEZ6 & 0 & 0 & 0 & 0 & 0 \\
\hline AEZ7 & 0 & 0 & 0.26 & 0.89 & -1.14 \\
\hline AEZ8 & 0 & 0.00 & 0.00 & 0.54 & -0.55 \\
\hline AEZ9 & 0 & 0.01 & -0.19 & 0.33 & -0.16 \\
\hline AEZ10 & 2.18 & 0.01 & -1.35 & -0.58 & -0.22 \\
\hline AEZ11 & 7.39 & -0.15 & -4.26 & -2.18 & -0.42 \\
\hline AEZ12 & 7.33 & -0.32 & -2.27 & -4.01 & -0.36 \\
\hline AEZ13 & 0 & 0 & 0.24 & 0.88 & -1.11 \\
\hline AEZ14 & 0 & 0.00 & 0.23 & 0.97 & -1.19 \\
\hline AEZ15 & 0 & 0 & 0.03 & 0.80 & -0.83 \\
\hline AEZ16 & 0 & 0 & -0.03 & 0.03 & 0 \\
\hline AEZ17, AEZ 18 & 0 & 0 & 0.00 & 0 & 0 \\
\hline China & Forestry & Paddy Rice & Other Grains & Other Crops & Ruminants \\
\hline AEZ1 - AEZ3 & 0 & 0 & 0 & 0 & 0 \\
\hline AEZ4 & 0 & -1.60 & 0.02 & 1.64 & -0.03 \\
\hline AEZ5 & 0.10 & -1.85 & 0.03 & 1.78 & -0.02 \\
\hline AEZ6 & 3.61 & -1.66 & -0.05 & -1.78 & -0.03 \\
\hline AEZ7 & 0 & -0.24 & 0.16 & 0.96 & -0.87 \\
\hline AEZ8 & 0.73 & -0.40 & -0.08 & 0.10 & -0.35 \\
\hline AEZ9 & 1.05 & -0.52 & -0.18 & -0.26 & -0.09 \\
\hline AEZ10 & 2.13 & -0.81 & -0.30 & -0.89 & -0.10 \\
\hline AEZ11 & 2.94 & -2.42 & -0.11 & -0.25 & -0.08 \\
\hline AEZ12 & 4.86 & -2.88 & -0.12 & -1.61 & -0.08 \\
\hline AEZ13 & 0 & -0.03 & 0.15 & 0.65 & -0.77 \\
\hline AEZ14 & 0 & -0.02 & 0.16 & 0.36 & -0.50 \\
\hline AEZ15 & 3.12 & -0.46 & -0.01 & 0.07 & -2.63 \\
\hline AEZ16 & 1.10 & -0.57 & 0.12 & 0.63 & -1.26 \\
\hline AEZ17 & 0 & -0.75 & 0.41 & 1.07 & -0.72 \\
\hline AEZ18 & 0 & 0 & 0 & 0 & 0 \\
\hline
\end{tabular}


Table 9. Changes in regional trade balances due to a $\$ 100 /$ TCE global carbon tax in agricultural sectors and forestry

\begin{tabular}{lccc}
\hline & \multicolumn{3}{c}{ Net Exports (\$/year) } \\
\cline { 2 - 4 } Sector & USA & CHN & ROW \\
\hline Rice & 594 & 16 & -619 \\
Other Grains & 2263 & 101 & -2279 \\
Other Crops & 2066 & 1041 & -2833 \\
Ruminants & 3686 & -545 & -2997 \\
Non-Ruminants & 1627 & -707 & -852 \\
Other Foods & 1642 & -633 & -498 \\
Forest Products & -4004 & 23 & 4472 \\
Fertilizer \& Energy Intensive Manufacturing & -1613 & 4965 & -1571 \\
Other Manufacturing and Services & -4761 & -2449 & 3866 \\
\hline Total & 1499 & 1812 & -3311 \\
\hline
\end{tabular}


Figure 1a. Global general equilibrium GHG abatement supply schedules

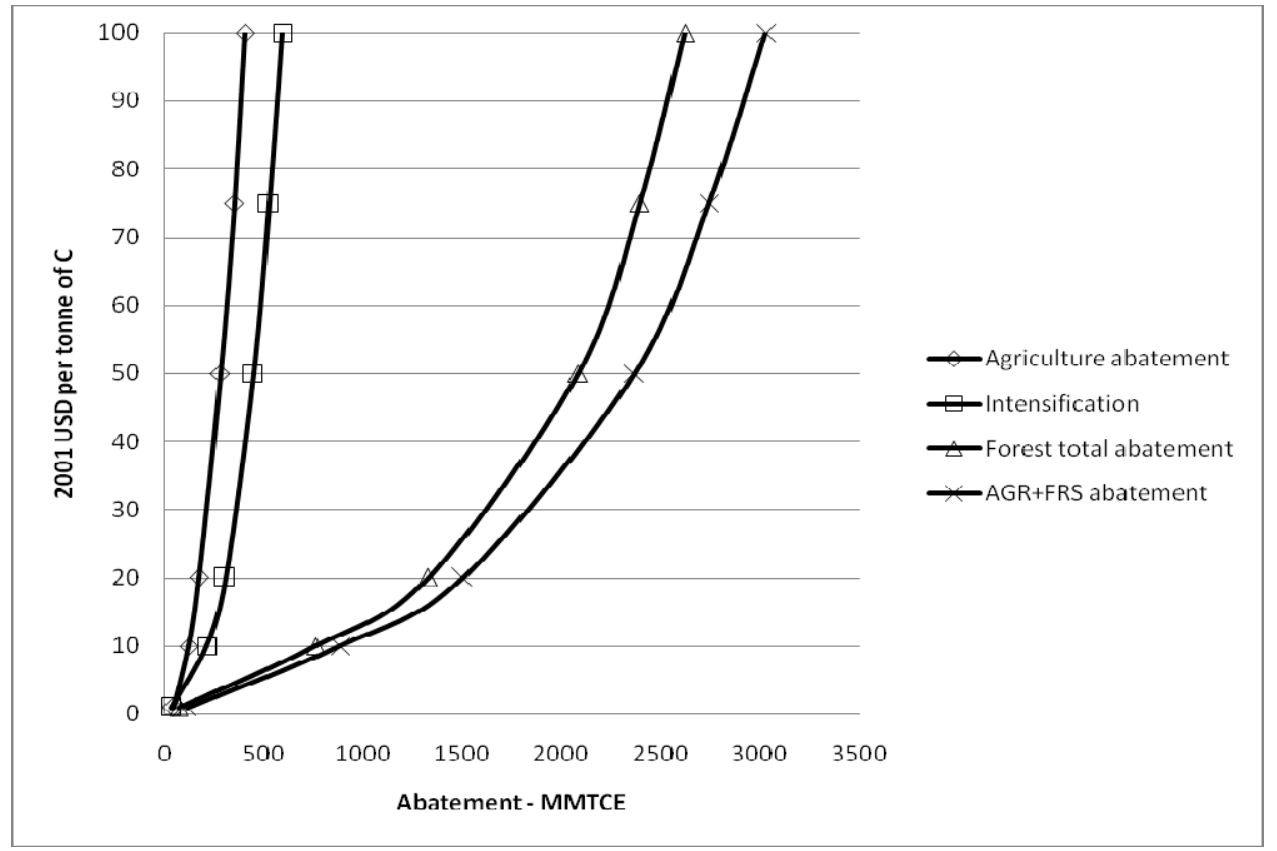

Figure 1b. Global agriculture subsector GHG abatement supply schedules

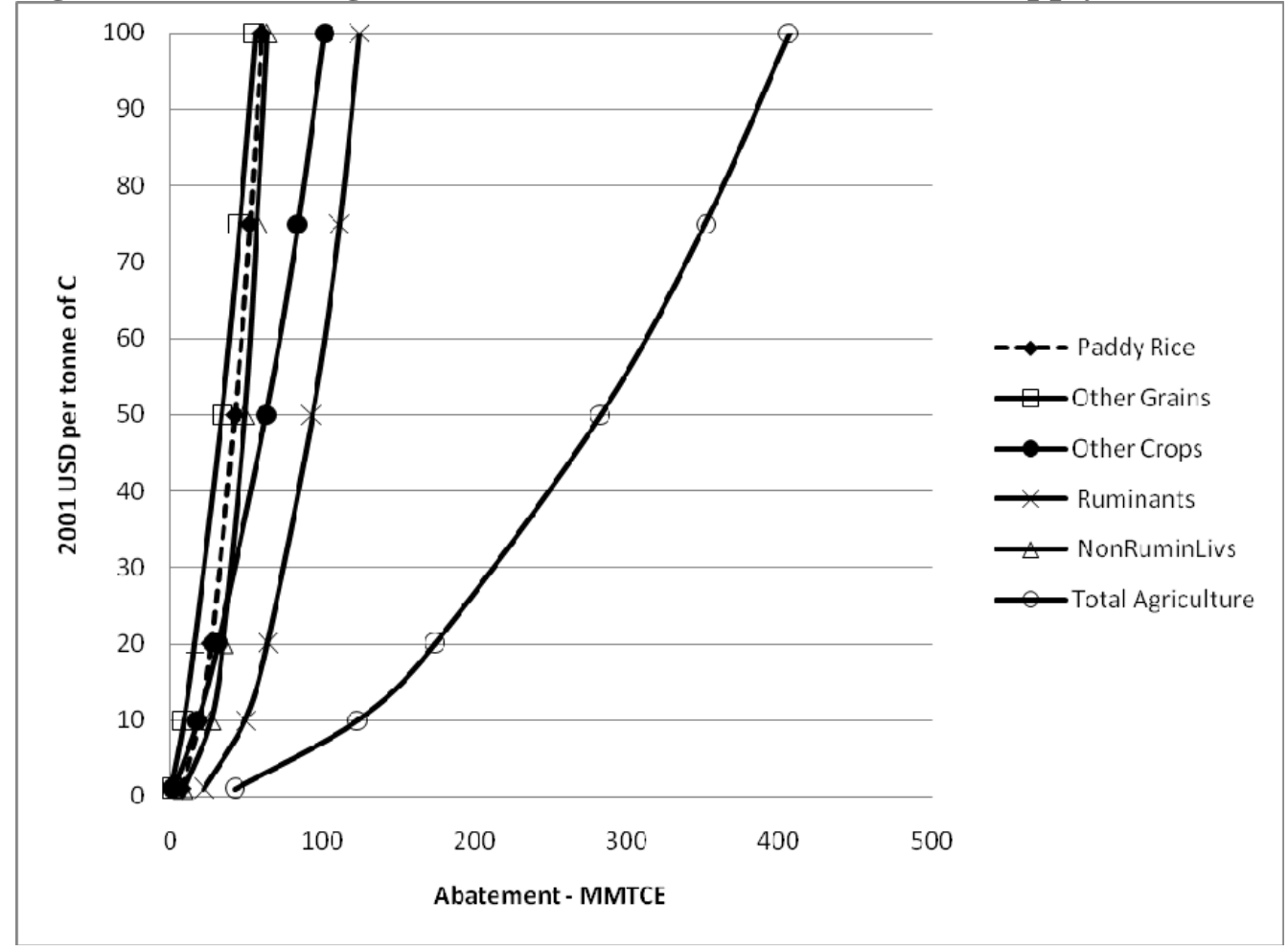




\section{Appendix}

In this appendix we explore the restrictions on our aggregate specification of technology in each country stemming from the "true model" in which we have a separate production function for each crop/AEZ pair in the country. Begin with the zero profit condition, as dictated by the maintained hypothesis of perfect competition. We know that for zero profits to hold, the percentage change in output price for $\mathrm{AEZ} j$, lower case $p_{j}$, must equal the cost share-weighted sum of the percentage changes in price paid (lower case $w_{i j}$ ) for input $i$ employed in AEZ $j: L_{i j}$ :

$$
p_{j}=\sum_{i} \theta_{i j} w_{i j}
$$

where $\theta_{i j}=W_{i j} L_{i j} / P_{j} Q_{j}$ is the share of total costs expended in the production of output in $\operatorname{AEZ} j$, $Q_{j}$ (upper case denotes levels variables). In the context of a global model, where there is a single factor market clearing condition for the non-land factors in each country, there must be a unique national market price for non-land inputs (e.g., fertilizer, or labor), so that $w_{i j}=w_{i k}$ for input $i$ used in both AEZs $j$ and $k{ }^{11}$ Similarly, if two sectors produce an identical commodity (e.g., wheat), then product prices will be the same, so their percentage changes will also be equal: $p_{j}=$ $p_{k}$. If, in addition, we make the assumption that non-land input-output ratios $\left(L_{i j} / Q_{j}\right.$ : e.g., kilogram fertilizer per bushel of maize) are the same across AEZs, then the non-land cost shares must also be equalized across sectors: $\theta_{i j}=\theta_{i k} \cdot{ }^{12}$ Therefore, we have the following result, where the $L$ subscript refers to land, and subscripts $j$ and $k$ refer to different AEZs producing the same product:

$$
\theta_{L j} w_{L j}=p_{j}-\sum_{i \neq L} \theta_{i j} w_{i j}=p_{k}-\sum_{i \neq L} \theta_{i k} w_{i k}=\theta_{L k} w_{L k}
$$

From equation (0.2) we see that the cost-share weighted percentage change in land rents across sectors must be equalized. Furthermore, since the cost shares must sum to one, and since the cost shares for non-land inputs across AEZs are equal as a consequence of equal input prices and equal input-output ratios, then so too must the land cost shares be equalized across AEZs: $\theta_{L j}=\theta_{L k}$. Importantly, this does not imply that the level of land rents will be equalized across AEZs. With differing crop yields, land rents must vary in direct proportion to yield, so that a low yield (high input-output ratio for land) will be precisely offset by a low level of land rents, thereby resulting in an equalization of land cost shares across AEZs. Since $\theta_{L j}=\theta_{L k}$, equation (1.2) gives us the result that: $w_{L j}=w_{L k}$. In order to ensure that the return to land in a given crop changes at the same rate, regardless of AEZ, we must assume that they are (nearly) perfect substitutes in aggregate agriculture and forestry production as described in the text.

\footnotetext{
${ }^{11}$ Of course, the firms' factor prices could differ due to taxes or subsidies that varied by AEZ sub-sector, but we do not have data at this level of detail (taxes are only reported at the sector level).

${ }^{12}$ The assumption of equal non-land factor intensities could be questioned. For example, the labor intensity (hours/bushel of corn) might be higher on low productivity land, and pesticide use could vary with rainfall or frost days. However, the only data available to us is that for the entire corn sector at the national level. So we have no real choice other than to make this assumption.
} 